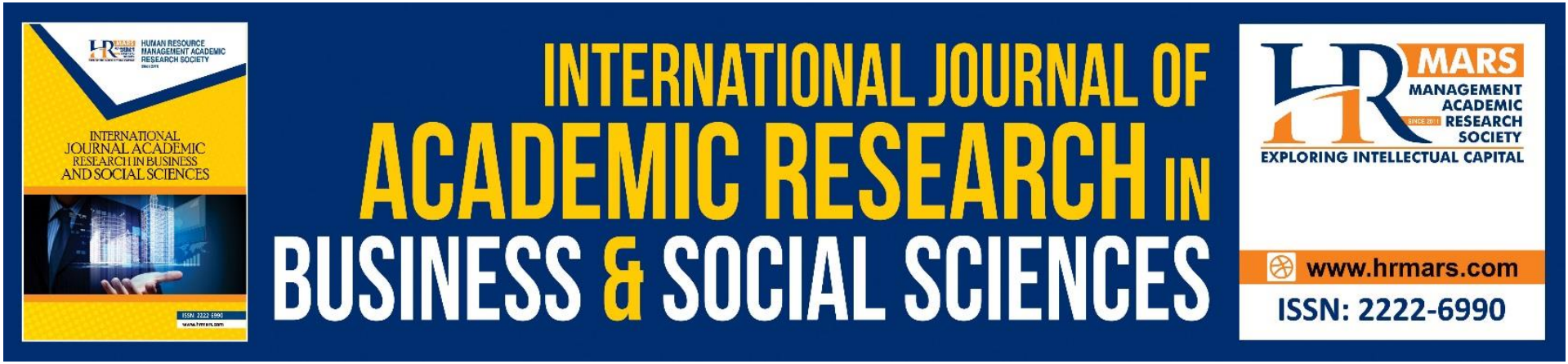

\title{
Inclusivity in Drug Abuse and Hiv/Aids Prevention Intervention: An Exploration on Fishermen Community Engagement
}

Ezarina Zakaria, Alya Ardini \& Fauziah Ibrahim

To Link this Article: http://dx.doi.org/10.6007/IJARBSS/v12-i1/12101

DOI:10.6007/IJARBSS/v12-i1/12101

Received: 13 November 2021, Revised: 17 December 2021, Accepted: 26 December 2021

Published Online: 16 January 2022

In-Text Citation: (Zakaria et al., 2022)

To Cite this Article: Zakaria, E., Ardini, A., \& Ibrahim, F. (2022). Inclusivity in Drug Abuse and Hiv/Aids Prevention Intervention: An Exploration on Fishermen Community Engagement. International Journal of Academic Research in Business and Social Sciences, 12(1), 827 - 840.

Copyright: @ 2022 The Author(s)

Published by Human Resource Management Academic Research Society (www.hrmars.com)

This article is published under the Creative Commons Attribution (CC BY 4.0) license. Anyone may reproduce, distribute, translate and create derivative works of this article (for both commercial and non0-commercial purposes), subject to full attribution to the original publication and authors. The full terms of this license may be seen

at: http://creativecommons.org/licences/by/4.0/legalcode

Vol. 12, No. 1, 2022, Pg. $827-840$

Full Terms \& Conditions of access and use can be found at http://hrmars.com/index.php/pages/detail/publication-ethics 


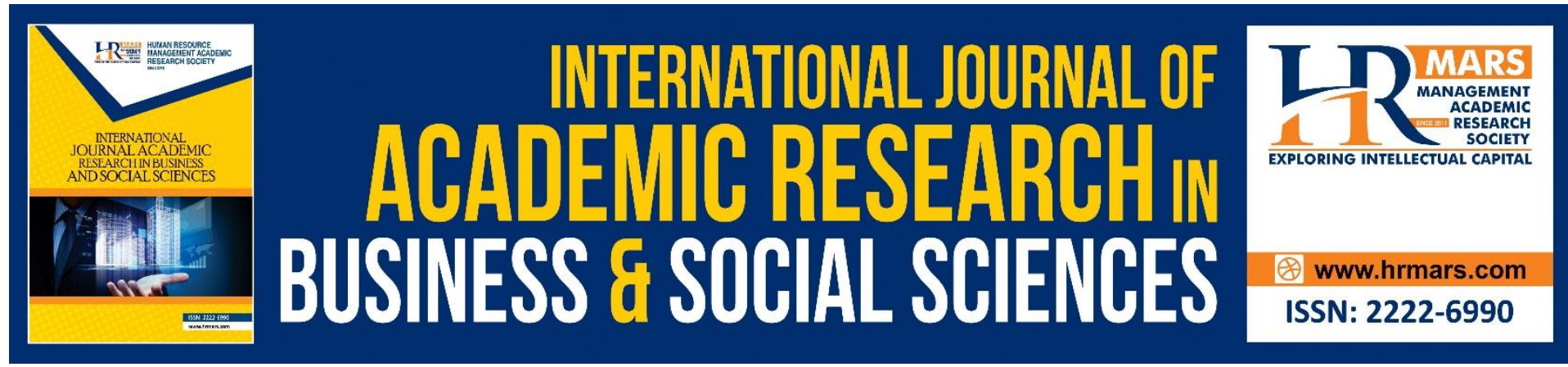

\title{
Inclusivity in Drug Abuse and Hiv/Aids Prevention Intervention: An Exploration on Fishermen Community Engagement
}

\author{
Ezarina Zakaria, Alya Ardini \& Fauziah Ibrahim \\ Social Work Program, Center for Research in Psychology and Human Well-Being, Faculty \\ of Social Science and Humanities, Universiti Kebangsaan Malaysia, 43600 Bangi, Selangor, \\ Malaysia \\ Correspondent Author: ezaz@ukm.edu.my
}

\begin{abstract}
Abtract
The inclusion or inclusivity of the B40 community especially among the fishermen community in integrated prevention interventions is very important to curb drug abuse and HIV/AIDS issues. The impact of drug injection using sharing needles has brought HIV/AIDS to the forefront as a global health issue. While, until these recent years drug abuse has become one of the uncured social problems. There are still lots of needed documentation on fishermen community inclusivity and their involvement in a preventive intervention. Research has been conducted to examine the involvement of fishermen communities in drug abuse and HIV/AIDS prevention interventions. This study is based on a Phenomenological design, with a total number of 10 fishermen in Kuala Perlis, Malaysia was selected as informants (5 youth representatives, and 5 adults representatives). Plus, data collection of this qualitative study was conducted using face-to-face interviews and analyzed by thematic analysis. The results show the informant i) is often involved and actively participates in prevention intervention programs, ii) their understanding of intervention objectives are good, iii) majority of them have never been joined or self-participated in any of planning and interventions implementation. Apart from that, the results found there is iv) limitations on community involvement in programs due to their nature of work as fishermen. While the inclusiveness survey showed v) stakeholder encouragement, vi) information sharing by agencies and local community leaders as well as vii) integrated involvement of various agencies in intervention programs were factors to encourage the involvement of the studied fishermen communities. In addition, this paper also emphasizes the need for community inclusivity in drug abuse and HIV/AIDS prevention intervention planning, especially for the B40 community.
\end{abstract}

Keywords: Drug and HIV/AIDS Prevention Interventions, Community Involvement, Fishermen Communities, Encouragement

\section{Introduction}

Inclusion or inclusivity describes the concept of appreciation for each individual's uniqueness aimed at creating a sense of respect and appreciation. Individual acceptance is different, giving full access to resources in the community, encouraging equal treatment, and opening 
up opportunities for self-improvement would explain more in detail the inclusion concept (Berger, 2020; Smith, 2019; Chavis, Lee \& Buchanan, 2001). Inclusion highlights the importance of recognizing community members as 'experts' in their own social environment. The individual appreciation for the "expert" is shown through providing opportunities for their active involvement including the rights for community members involved in decision making (Chavis et al., 2001). The main aspect that need to be focused are i) social relationship and sense of belonging, ii) age friendly, and iii) community prosperous.

The integration of prevention intervention on inclusivity community among the B40 especially the fishermen community is important in curbing drug abuse and HIV/AIDS. As we know, the impact of needle sharing among drug users has gained attention as a global health issue, and become completely unprevented or can be considered as one of the uncured social problems nowadays. Statistics has shown the increasing numbers of drug addiction in relapses and new addiction in Malaysia. According to The National Anti-Drug Agency (2019), in the year 2018, Malaysia has recorded a total of 130788 addicts of drug addicts and substance abuse, and the numbers keep a rise for the following year to 142199 persons. Similarly, statistics on the estimated number of new patients infected with HIV/AIDS in Malaysia also showed an increase. In a report released by the Ministry of Health Malaysia (2019) through the Country Progress Report On HIV/AIDS Malaysia, a total of 6100 people were infected with HIV in 2018 compared to only recorded 2297 people in 2016. Meanwhile, statistics by the state in 2019 have shown Perlis recorded a $0.5 \%$ increment of cases of HIV/AIDS compared to the other states. Therefore, the implementation of comprehensive preventive interventions involving the full participation of community members is important and seen as an initial step in drug abuse and HIV/AIDS prevention. So to understand issues regarding community involvement in preventive intervention more research on community inclusivity is needed in the future.

\section{Community Inclusivity in Prevention Intervention Planning for Drug Abuse and HIV/AIDS}

Community inclusion or inclusivity is a key mechanism in the planning of prevention programs (Hasli et al., 2016). This is the main indicator concpet in evaluating effectiveness of prevention program. There are five key approaches and efforts to mobilize community inclusion in intervention planning such as i) profiling create, ii) community assessment needs, iii) community assessement readiness, iv) empowering community, and v) field expert consultation. The success and effectiveness of drug prevention programs can be seen from community involvement at the program planning stage. At this stage community leaders play a role as driven factors in epitomizing community involvement during the drug prevention program planning process. Followed by NGOs, private sectors, also individuals. Research from The National Institute on Drug Abuse (2003), stated at the early stage of prevention program selection, the community should have full authority to decide intervention programs that meet their needs and the appropriate resources/assets available in the community.

Next, discussion on the need for community inclusivity in preventive interventions also can be related to the role of professional practitioners using specific approaches in encouraging community member involvement. Study by Substance Abuse and Mental Helath Service Administration (SAMHSA) (2018), focus more on practitioners role in leveraging skills and resources in the wider environment, just to ensure the importance of community involvement throughout the program planning process. In addition, the collaboration between communities, agencies, stakeholders are also emphasized in planning prevention 
programs. This is because the program plan process can not be successful due to involvement from one party. Accordingly, there are five measures proposed by SAMHSA (2018) as a possible collaboration between the community and the agencies involved particularly at the planning stage, such as i) assessment, ii) capacity, iii) planning, iv) implementation, and vi) monitoring.

First stage i) assessment, communities need to identify the prevention needs and maximize their environmental information, capacity and determine key issues of drug abuse and HIV/AIDS. At the second stage ii) capacity, community members should prepare to address the drug abuse and HIV/AIDS issues, also develop environmental resources. At the third stage iii) community role in developing a comprehensive plan to address drug abuse and HIV/AIDS issues. Fourth stage iv) community members' action in delivering dan refining selected prevention programs. Lastly at the fifth stage $v$ ) monitoring and examining the process and outcome of the implemented programs in their locality.

The need for inclusivity prevention programs is not only limited to drug abuse but also includes the impact on HIV/AIDS. According to Jose et al (2017), the community will actively get involved in the planning and development of HIV/STI prevention care programs. Besides, the community inclusivity involvement also can be seen through dialogue concept programs between youth, stakeholders, and practitioners in emphasizing the impact of prevention intervention of HIV/STI. The reciprocal relationship between community members and stakeholders is established. Results of the Jose study recommend four steps as initiatives in structuring and developing programs such as i) implementing community dialogue, ii) community members recruitment through informative advertisement, iii) dialogue evaluation, and iv) intervention activities selection by the stakeholders.

Rationally, the implementation of such dialogues can provide opportunities for community members to participate in the decision-making process and program planning. Apart from that, achievements from previous prevention programs also can be used as reference sources in planning for upcoming community-based intervention programs. The dialogues illustrate inclusivity community methods had created feasibility, acceptability, sustainability and combination ideas from various stakeholders. Particularly to achieve effective HIV/AIDS prevention interventions for the target group.

\section{Community Involvement Factors}

Full involvement of the target group is a key element of the success of an intervention. Research by Lawrence (2011) explained full involvement from the community in prevention intervention programs plays an important role in risk-reducing of those epidermic. The initial research on the need for the intervention implementation inside the community would influence the appropriateness and relevance of community involvement and also can be considered as driven factors for those conducted intervention. Previous research by Supranee (2015) on the involvement among the Sawadwarisemi Temple community in Bangkok, Thailand found that community committee members, local leaders, religious members (monks), and adults were the driving factors of involvement in drug abuse prevention programs. They are responsible for i) monitor, report, and providing misconduct information happen in the community to the community leaders, ii) motivating the community in managing and problem-solving drug abuse problems, also applying the community and family 
committee approach mechanism to provide drug awareness for the community. Other than that iii) work with law enforcement to conduct drug screenings at community centers, iv) participate in community empowerment and development programs. Lastly, v) financial asistant and energy to launch community development programs.

The study outcome also shows the government played an important role in empowering the community to get involved in drug abuse issues, especially activities related to drug prevention programs. Besides, Integrated encouragement from the government and problem-solving skills instilled through drug prevention programs are important efforts in resolving drug abuse issues in the local community (Kongudom, 2002). Furthermore, accessibility, a desire to get involved, and knowledge about the implemented activities are key factors of community involvement in substance abuse prevention programs. Indeepth exploration on sociodemographic factors by the implementing agencies also very important to see to what extend of community response in the prevention program being carried out. This is because the results of the study show the low-income community involvement in substance abuse prevention programs is well received and accepted (Kauffman \& Poulin, 1994; Robert et al., 2017). Thus from the previous program, we can see the outstanding feedback and goal achievement of the issues related to substance abuse becoming more prevalent among the targeted community. Plus, awareness among community members about the effects of substance abuse also encourages community active involvement in the conducted prevention programs (Peterson \& Reid, 2003).

Moreover, a study from Robert et al (2017) found that community members who care about well -being in the neighborhood have a higher level of involvement in the program, also volunteering to work with implementing agencies in the process of designing and implementing effective prevention activities. The main purpose is to overcome negative perceptions among members of the community towards the authorities while addressing the substance abuse issues. Next, if there is initial research on the possibility of a community facing HIV/AIDS risk in the environment, then it is easier for them to take part in an intervention program organized by the authorities. As a result, community involvement in preventive interventions affects the effectiveness of the interventions carried out (Valentine \& Nancy, 2018).

In addition, previous research by Amanda (2005) has focused on youth involvement in drug abuse prevention intervention. The result shows the exploration success and stakeholders react ability able to influence youth involvement level during the implementation process. Furthermore, integrated involvement in the intervention can form strong self-confidence. In short, although the concept of involvement is understandable the limitation or research gap still existed in this study. Based on the previous researchers, they have focused more on youth involvement, while the recent research has conducted more studies on community involvement. Rationally, all groups in the community deserve to accept and get involved in intervention programs (National Strategic Plan, 2015). Finally, we can say community involvement in preventive interventions is at full level. Previous studies also illustrate involvement as a form of an individual's ability to voluntarily participate in implemented preventive interventions. Although there is existed research gap from previous studies that were highlighted, it proves the differences in target group involvement even though the context of the studies is similar. On the other hand, the overall ideas from previous studies provide an interesting framework, especially in researching the involvement of drug abusers and HIV/AIDS prevention intervention among the Fishermen Community located in Kuala Perlis. In particular, this study was conducted to idenfity the extent of community inclusivity 
by exploring a fishermen community involvement in drug abuse and HIV/AIDS prevention intervention.

\section{Methodology}

Phenomenological qualitative research methods were used in this study. According to Creswell (2014), qualitative research approaches were used to explore and understand social problems that bring meaning to an individual or group of people. Meanwhile, phenomenological design describes the meaning of experience regarding concepts or phenomena that have occurred to individuals (Van Manen, 1990). The study location is in Kampung Seberang Alor, Kuala Perlis, and was chosen based their B40 economic status group among fishermen community living in rural areas. The B40 among the fishermen community is often the main focus among the stakeholder for implementing their drug abuse and HIV/AIDS risk-reduction programs.

A total of 10 people from the Kuala Perlis fishermen community consisting of five adults and youths ( 5 people) were selected using purposive sampling. Study sample youth and adults (group) was selected based in the justification cases from the increasing number in productive age. Based on the statistics by AADK (2020), both groups have recorded the highest numbers of drug abuse cases from January until June in 2019. Plus the Ministry of Health or $\mathrm{MOH}(2020)$ also reported those two group has the highest numbers of HIV/AIDS positive cases. The study was conducted using face-to-face with a semi-structured interview method. This method was chosen based on field-based research suitability that was conducted in the fishing village of Kuala Perlis. According to Burgess (1984), a semi-structured interview is a conversation conducted based on the central focus of the discussion.

Next, open-ended interview questions were conducted based on the study objective appropriate to the research questions. Two main sections of the interview questions were formed. Section A focused on questions related to the informant demographics, whereas section B covers the scope related to the fishermen community involvement located in Kuala Perlis in drug abuse and HIV/AIDS prevention intervention. Finally, the study also applied thematic analysis as a method for data analysis. According to Braun \& Clarke (2006), thematic analysis is used to identify, analyze and determine the study theme from the data collecting process from the informants. There are six phases in the thematic analysis such as i) data familiarize, ii) creating preliminary codes, iii) finding themes, iv) revision theme, v) theme determination, and iv) writing a report.

\section{Results and Discussion}

\section{A) Informan Demography}

The demographic background of the study is divided into two groups i) 5 informant from adults group age from 31 years old and above, and ii) 5 informant from youth group age from 18 to 31 years old. The results of the study are presented to report the demographic information of each informant according to section A questions.

\section{Adults}

Based on table 1, more than half of the informants interviewed are female, and the age range is from 31 years old to 40 years old above. Overall, the adult informants in this research were Malay, Muslim and married. In addition, from the data obtained three aout of five informants work as food seller, fisherman, store assistant, whereas the other two are full- 
time housewives. All of them belong to the lowest 40 percent economic income composition (B40) with a monthly average wage of RM 3860.00 (Ahmad Zubir Ibrahim, 2017; Household Income and Expenditure Survey (HIES), 2014). According to the informants in this study, their monthly salary is around RM 800.00-RM1500.00.

Table 1: Adult Informan Demography Information

\begin{tabular}{|c|c|c|c|c|c|c|c|c|}
\hline $\begin{array}{l}\text { Informant } \\
\text { Demography }\end{array}$ & Informant & $\begin{array}{l}\mathrm{S} \\
\mathrm{e} \\
\mathrm{x}\end{array}$ & $\begin{array}{l}\text { A } \\
\text { ge }\end{array}$ & Race & $\begin{array}{l}\text { Religio } \\
\text { us }\end{array}$ & $\begin{array}{l}\text { Maritial } \\
\text { Status }\end{array}$ & Occupation & $\begin{array}{l}\text { Monthly } \\
\text { Income }\end{array}$ \\
\hline \multirow{5}{*}{$\begin{array}{l}\text { Group of } \\
\text { Adult } \\
\text { Informant }\end{array}$} & $\begin{array}{c}\text { Informant } \\
\text { A }\end{array}$ & $F$ & 45 & Malay & Muslim & Married & Food Seller & RM 1500.00 \\
\hline & $\begin{array}{c}\text { Informant } \\
\text { B }\end{array}$ & $\mathrm{F}$ & 47 & Malay & Muslim & Married & Housewife & RM 0.00 \\
\hline & $\begin{array}{l}\text { Informant } \\
\text { C }\end{array}$ & $\mathrm{F}$ & 57 & Malay & Muslim & Married & Housewife & RM 0.00 \\
\hline & $\begin{array}{c}\text { Informant } \\
\text { D }\end{array}$ & $M$ & 47 & Malay & Muslim & Married & Fisherman & $\begin{array}{l}\text { RM } 800.00- \\
\text { RM } 900.00\end{array}$ \\
\hline & $\begin{array}{c}\text { Informant } \\
E\end{array}$ & $\mathrm{~F}$ & 39 & Malay & Muslim & Married & $\begin{array}{l}\text { Store } \\
\text { Assistant }\end{array}$ & RM 800.00 \\
\hline
\end{tabular}

$N=5$ persons 


\section{Youth}

Data analysis showed the majority of youth informants interviewed by the researcher in Kuala Perlis are also female, with the age range between 19 years old to 30 years old, all are Malay and Muslim by race and religion. In addition, in terms of marital status, data have found that the majority of youth informants are married and whereas the other two are still single. Apart from that, the study data also stated there only three informants are working, two of them work as restaurant assistants, and one of them is a daily worker as lawn mowing, whereas the other two are full-time housewives. Their monthly income is between RM 200.00- RM 1000.00 and belong to the lowest 40 percent economic income composition group (B40).

Table 2: Youth Informan Demography Information

\begin{tabular}{|c|c|c|c|c|c|c|c|c|}
\hline $\begin{array}{c}\text { Informan } \\
t \\
\text { Demogra } \\
\text { phy }\end{array}$ & Informant & Sex & Age & Race & Religious & $\begin{array}{c}\text { Maritial } \\
\text { Status }\end{array}$ & Occupation & $\begin{array}{l}\text { Montly } \\
\text { Income }\end{array}$ \\
\hline \multirow{5}{*}{$\begin{array}{l}\text { Group of } \\
\text { Youth } \\
\text { Informan } \\
t\end{array}$} & $\begin{array}{c}\text { Informant } \\
\text { A }\end{array}$ & $\mathrm{F}$ & 19 & Malay & Muslim & Single & $\begin{array}{c}\text { Restaurant } \\
\text { Helper }\end{array}$ & $\begin{array}{c}\text { RM } \\
500.00\end{array}$ \\
\hline & $\begin{array}{c}\text { Informant } \\
\text { B }\end{array}$ & $\mathrm{F}$ & 24 & Malay & Muslim & Married & $\begin{array}{l}\text { House } \\
\text { wife }\end{array}$ & RM 0.00 \\
\hline & $\begin{array}{c}\text { Informant } \\
\text { C }\end{array}$ & $F$ & 30 & Malay & Muslim & Married & $\begin{array}{l}\text { House } \\
\text { wife }\end{array}$ & RM 0.00 \\
\hline & $\begin{array}{c}\text { Informant } \\
\text { D }\end{array}$ & $M$ & 21 & Malay & Muslim & Single & $\begin{array}{c}\text { Daily worker } \\
\text { (Lawn } \\
\text { Mowing) }\end{array}$ & $\begin{array}{c}\text { RM } \\
200.00\end{array}$ \\
\hline & $\begin{array}{c}\text { Informant } \\
E\end{array}$ & $\mathrm{~F}$ & 28 & Malay & Muslim & Married & $\begin{array}{c}\text { Restaurant } \\
\text { Helper }\end{array}$ & $\begin{array}{c}\mathrm{RM} \\
1000.00\end{array}$ \\
\hline
\end{tabular}

$N=5$ persons

Fisherman Community Involvement in Drug Abuse and HIV/AIDS Prevention Intervention Based on the data analyzed, several themes regarding the involvement of the Kuala Perlis fishermen community in drug abuse and HIV/AIDS prevention interventions have been identified. Their involvement in these drugs abuse and HIV/AIDS prevention intervention stationed on previous implemented intervention series. This article will present the extent of informants involvement (both groups) in preventive intervention from the aspect i) their frequency level in programs involvement, ii) attendance commitment, and iii) motivational factors for involvement.

\section{i) Frequency: Active Involvement}

Frequency of involvement refers level of informants engage in preventative interventions that have been implemented in the fishermen community. The results from the analysis found, all informants from adults ( 5 persons) and youth groups (5 persons) in this community are actively involved in drug abuse and HIV/AIDS prevention intervention. Both groups of informants have stated that they were involved with an average of three times a year in thoses programs. 
According to one of the adult informant; "...here in Kampung Alor twice, three times a year ..." (Adult Informants E (39), Kuala Perlis) in a program for Fishermen Community in Kuala Perlis. The youth informant E also stated that; "for those programs like drug prevention and HIV/AIDS program, I get involved for about two or three times in a year" (Youth Informants $\mathrm{E}$ (28), Kuala Perlis).

Overall, the findings of the study indicate that all informants can be considered to have been actively involved in the preventive interventions implemented. Their willingness to participate and the effectiveness of those prevention intervention programs (drug abuse and HIV/AIDS) can be assessed and influenced based on studied informants' frequency involvement level.

These findings are parallel with the study conducted by Valentine \& Nancy (2018) saying that the implementation of interventions is more effective in the presence of integrated involvement by the community. According to Lawrence Mbuagbaw \& Elizabeth Shurik (2011), Integrated community involvement in HIV/AIDS prevention interventions is influenced by several components such as the importance of community health care, the effectiveness of research on the implementation of interventions, and community peer educators influences. Besides, research by United Nations Office for Drug Control and Crime Prevention Vienna (2016) also stated community active involvement in drug prevention is closely related to the effectiveness in delivering intervention implemented by the authorities at all levels. In summary, the community will be interested to participate if they are confident with the effectiveness of those intervention programs

\section{ii) Attendance Comitment: Full Attendance during The Ongoing Prevention Intervention}

Analysis of the interview data regarding the presence of the informants during the intervention found that the informants chose either a) commit to participate in the program for the whole day or b) half a day only. Adult informants consist adult informants A, B and C stated they had been attended the prevention program throughout the day until the end of the program session, for example one informant stated that he; "I had attend the intervention program for the whole day, I waited until the end of the programs" (Adult informant B 47), Kuala Perlis).

Apart from that, majority informants from youth group (Youth informants $A, B, C$ and $E$ ) also shared their experience in programs involvement throughout the session. Out of four, one from the youth informant stated; "Yes, I do attend those programs from morning to evening" (Youth Informant B (24), Kuala Perlis). Besides, occupational factors had influence informants full attendance in preventive interventions. Majority of the informants from adults group were fully participate in those preventive intervention programs are full-time housewives or self-employed. Similar scenario occurs for youth informants group, majority of the programs participants are housewives and those working in the same area with program location.

Informants were found to have more flexible time to be fully present in the prevention programs conducted compared to those with tied work schedules. Location (closer to their workplace), flexible work schedule, and incentives also play an important role in attracting informant's attendance. These results are parallel with researches conducted by (Zakaria, et al., 2020; Zakaria, et al., 2021; Bierman et al., 2011). With incentives provision, flexible schedules, personal relationships, and full support from community representatives are seen as important aspects to maintain and attract more community members to prevention programs. 
However, some of the informants were also unable to be fully attended the intervention session. Informant D (adult) admitted to only attending the programs in the afternoon; "I came but only in the evening" (Adult Informant D (47), Kuala Perlis). The same goes for youth informants $A$ and D. Youth informant $D$ was only attend the intervention in the afternoon; "I always go in the evening" (Youth Informant D (21), Kuala Perlis).

Occupational factors have limited their time to attend the implemented preventive interventions. According to adult informant $A$, working as fishermen will demand him to begin his work in the early morning up to noon. Therefore, to ensure the community's full involvement in preventive interventions, the implementation of the intervention must meet the needs, comply with the norms and differences of living culture, also the socio-economic routines of the community (United Nations Office on Drug and Crime, 2020). In addition, those implemented programs should also meet certain standards, by the stipulations of the implementing agency, adequate funding sources from government or state agencies. So the intervention should be adapted to the culture and needs of the community, in order to have the community full involvement in the intervention (Halfors et al., 2007; Conell, 2009).

\section{iii) Engagement Motivation Factors}

Exploration on the involvement of fishermen communities in drug abuse and HIV/AIDS prevention intervention programs will be better understood when the driving factor's involvement is identified. There are two themes of motivating factors had been identified a) intrapersonal factors: self-concept and sense of responsibility to help the community also b) positive influence from the social system.

\section{a) Interpersonal Factors: Self -Concept and Sense of Responsibility in Helping the Community}

Based on the data analysis, majority of adult informants' paricipancy in those intervention programs is driven by intrapersonal factors such as self-concept and sense of responsibility in helping their own communities. Both informants $A$ and $B$ from adults group have stated similar view;

"...personally, I am really interested. This is because I do not want any of these teenagers, adults and children to get involved with drugs.." (Adult Informan A (45), Kuala Perlis)

Apart from that, she (adult informant A) was voluntarily participating in the preventive intervention program. Informant itself has a sense of responsibility to get involved in those programs with intention to help at-risk groups such as children and adolescents from engaging in drug abuse and HIV/AIDS activities among her community members.

"As an active community members, we are always interested to join any programs related to our community, if we knew of any programs held in this neighbourhood or even nearby community, if the organisers and community leaders informs us and we definitely attend those program"(Adult Informant C (57), Kuala Perlis)

However, adult informants $C$ and $D$ stated their participation in those programs was due to their position as committee members in the association residents. These findings illustrate the sense of responsibility towards their community members, both informants saw the need for them to be actively involved in every implementation program.

In a conclusion, the interest factors, sense of responsibility in helping at-risk groups, and role as committee members in the resident association were closely related to informants 'reaction in voluntarily engaging themselves in preventive interventions. According to Human 
Rights and Gender Equality in Health Sector Strategies (WHO) (2020), voluntary participation in organized programs would affect the individual's life functioning in the process of effective decision-making. Plus integrated involvement in interventions will build strong selfconfidence (Poole, 2005). Thus, this study finding reinforces views on self-motivation produces voluntary involvement behaviors to get participate in prevention intervention programs including the fishermen community. Engagement with such encouragement indirectly enhances the social functioning of the community.

\section{b) Positive Influences from Social System}

The results of the analysis have found both groups of informants involved in drug prevention interventions and HIV/AIDS were influenced by their social systems. According to one of the adult informants, her involvement in those programs was influenced by the commitment of the local leader; "it is on the resident committee.." (Adult Informant E (39), Kuala Perlis). She emphasized that it was the local leader get her involved in the preventive programs.

Besides, the data analysis also found local leaders successfully played an important role in influencing community members to be involved in the interventions implemented. Similar opinion stated by the youth informants $B$ and $E$, their local leaders positively influenced them to be actively involved in the interventions implemented;

"...our local leader the one who is responsible in encourages us (most villagers) to participate in those programs. He is our village leader, somekind like JKK.." (Youth Informant B (24), Kuala Perlis)

In addition, there are also other individuals influencing the informant's involvement. Youth informants $C$ and $E$ were positively motivated (no coercion or instruction) to engage in the preventive interventions that had been implemented. This is due to positive influence from their peers;

"At first, it was my initiative and interest to get participates but later there was a friend (one of the program committee members) invited me to join their next program." (Youth Informant E (28), Kuala Perlis)

Next, the research also found youth informants $A$ and $D$ tell their participation and involvement in the preventive intervention was positively influenced by their mothers. According to youth informant $A$, it was the mother who is insisted and repeatedly tells her to get involved because she is extremely confident that the program would increase her daughter's knowledge of HIV/AIDS and drugs.

"My parents encouraged me to joined the program, so I can gain more knowledge about drugs and HIV"

\section{(Youth Informant A (19), Kuala Perlis)}

The finding showed positive influences from other individuals such as JKKK members, parents, and peers in the informant's environment systems will successfully influence their involvement (both groups informants) in the interventions programs. Both groups of informants made important individuals around them a catalyst for more active engagement, for example the JKKK's, parents, and peers. In addition, direct interaction involved between informants and other individuals in terms of information transfer also occurs (Galvani, 2017). Finally, these findings are also supported and expressed by the other referral researchers such as Fauziah et al (2013); National Drug Control Policy (2011); Ezarina et al (2020), the involvement of other social systems such as family members and community in client's environment is important for implementing a more integrated drug prevention intervention program. Plus, family cooperation in prevention programs is also seen as an important aspect 
to reduce the risk-behaviors involvement in drug abuse. This includes a discussion by Nazariah et al., (2019) regarding online prevention programs as well as new media.

\section{Conclusion}

In a conclusion, the involvement of the Kuala Perlis fishermen community in drug abuse and HIV/AIDS prevention interventions is frequent and active. Thus, their active involvement has increased community members understanding at a better level even though the majority of them do not hold any position in the planning and implementation of interventions. At the same time, the limitations of community members' involvement in preventive interventions are shaped by their nature work itself. As fishermen who is work from early morning until noon will usually refrain themselves by limiting their time from getting involved in any intervention programs. They prefer to spend their free time relaxing and repairing fishing equipment. However, the encouragement from the various integrated sources and collaboration from the stakeholders, information delivering agencies, and local community leaders will be driven factors in community involvement in drug abuse and HIV/AIDS prevention intervention programs.

Commenting on the findings of this study from a different point of view, it is certain that the latest requirements related to the COVID-19 endemic also affect community involvement. Although results of the study as a whole indicate, the involvement of the fishermen community in the intervention is frequent and active but the COVID-19 pandemic limits integrated implementation.Therefore, we deeply hope that organizations at the community level and the implementing agencies can take into account suitability in finding the latest initiative to create new preventive intervention programs due to the current Covid-19 pandemic situation of our country. This is especially for the continuity and accessibility of the program at all levels of the community. Organizing prevention webinars, continuous information sharing on the effects and dangers of drugs and HIV/AIDS on social media, or infographics are initiatives that should be suggested. The implementation can be done in various forms and not only involves physical encounters but it can also be done in the simplest ways as long as it is suitable and applicable to our new norms. To this end, internet accessibility and technical mastery aspects among the fishermen community to remain involved in online prevention programs also need to be given special attention.

\section{Refrences}

Agensi Antidadah Kebangsaan. (2019). Statistik dadah. https://www.adk.gov.my/orangawam/statistik-dadah/

Agensi Antidadah Kebangsaan. (2019). Statistik dadah. https://www.adk.gov.my/orangawam/statistik-dadah/

Amanda, P. (2005). Youth participation in drug prevention programmes. https://rm.coe.int/1680746036.

Ibrahim, I., Alavi, K., \& Hassan, N. (2020). Penulisan Tesis Kajian Kualitatif dan Kuantitatif. Universiti Kebangsaan Malaysia.

Jai, K. D., Rehana, A. S., Ahmed, A., Yaron, F., \& Zulfiqar, A. B. (2016). Interventions for adolescent substance abuse: An overview of systematic reviews. 10.1016/j.jadohealth.2016.06.021.

John, W. C. (2012). Research design: qualitative, quantitative and mixed methods approaches (4rd ed.). Los Angeles 
Kapilla, A., Chaudhary, S., Sharma, R. B., Vashist, H., Sisodia, S. S., \& Cupta, A. (2016). A review on: HIV/AIDS. Indian Journal of Pharmaceutical and Biological Research (IJPBR) 4(3), 6973

Lawrence, A., Palinkas, S. M., Horwitz, C. A. G., Jeniffer, P. W., Naihua, D., \& Kimberly, H. (2016). Purposeful sampling for qualitative data collection and analysis in mixed method implementation research. HHS Public Access 42(5), 533-544

Lembaga Kemajuan Ikan Malaysia (LKIM) \& Universiti Putra Malaysia. (2014). Kajian mengenai tahap penyalahgunaan dadah dalam kalangan nelayan di Malaysia. https://umexpert.um.edu.my/public_view.php?type=publication\&row=NzgxMjM\%3D.

Mbuagbaw, L., \& Shurik, E. (2011). HIV-infection- impact, awareness and social implications of living with HIV/AIDS. In Younde \& Miami (Eds.), Community participation in HIV/AIDS programs, (pp. 214-222). McMaster University.

Ministry of Health Malaysia. (2015). National strategic plan: Ending AIDS 2016-2030.

Ministry of Health Malaysia. (2019). Country progress report on HIV/AIDS 2019.

Nurzaimah, A., Ezarina, Z., \& Haris, A, W. (2013). Intervensi kerja sosial sekolah dalam menangani masalah sosial pelajar. Jurnal Pendidikan Malaysia 38(1), 42-51.

Oedojo, Soedirham. (2007). HIV/AIDS sebagai isu 'human security'. Jurnal Promosi Kesehatan 1(1), 25-35.

Reychad, A., Murat, A., Holly, A., \& Oscar, A. (2017). Prevention of drug use and treatment of drug use disorders in rural settings. New York United Nations.

Robert, J. R., Brad, F., David, T. L., \& Pauline, G-R. (2017). Exploring the predictors of citizen participation in substance abuse prevention activities. Journal of Alcoholism \& Drug Dependence 5(2), 1-10.

Sara, S. M. S., \& Asnarulkhadi, A. S. (2011). Tahap penglibatan komuniti orang asli dalam pembangunan komuniti di Semenanjung Malaysia. Journal of Human Capital Development 4(1), 125-139.

Sarah, G. (2017). Social work and substance use: Ecological perspectives on workforce development. Drugs: Education, Prevention and Policy 24(6), 469-476.

Supranee, W. (2015). Community participation to solve illegal drugs problems. Social and Behavioral Sciences 197(2015), 2145-2150.

Tyndale, E. M., \& Coyle, C. B (edt). The Effectiveness of Community Intervantions Targeting HIV and AIDS Prevention of Young People in Developing Countries: A Systematic Review of The Evidence From Developing Countries. In Ross, David A., Dick, Bruce, Ferguson, Jane. Eleanor Maticka-Tyndale \& Chris Brouillard-Coyle, Preventing HIV/AIDS In Young People: A Systematic Review of The Evidence From Developing Countries (pp.243-281). Geneva Switzerland.

Valentine \& Nancy. (2018). Community participation in drug use and abuse intervention: A call for access to information. Paper Presented in NACADA-ISSUP International Conference on Drug Demand Reduction 2018 "Thinking Globally, Acting Locally". Nairobi.https://www.researchgate.net/publication/336398053_Community_Participat ion_in_Drug_Use_and_Abuse_Interventions_A_Call_for_Access_to_Informati.

Wan. N., Wan, N. F., Wan, N., \& Adi, F. (2018). Pelaksanaan dan keberkesanan program penyalahgunaan dadah dalam kalangan pelajar di sekolah-sekolah menengah di Gabungan Kota Kinabalu, Sabah. Asian Social Work Journal 3(4), 36-41.

Zakaria, E., Ibrahim, F., \& Hassan, N. (2020). Hubungan antara penerimaan, kesediaan, logistik dan insentif dengan penglibatan program pendidikan pencegahan dadah dalam kalangan keluarga B40. Jurnal Psikologi Malaysia 34(2), 184 - 194. 
Zakaria, E., Ibrahim, F., \& Naser, A. (2021). Sustaining the Low Income Family Participation in Drug Prevention Based Program: The Promising Factors. International Journal of Academic Research in Business and Social Sciences, 11(6), 1065-1075

Zarina, O., Azizian, N. I., \& Mohamad, D. D. (2015). Penyalahgunaan dadah sebagai ancaman keselamatan: analisis keberkesanan program kerajaan dalam mengekang pengrekrutan penagih dadah di Malaysia. Malaysian Journal of Society and Space 11(13), 60-71. 